trated sulphuric acid. A suitable sprayer bottle is described by Kirchner et al. ${ }^{6}$. The plate is then heated in an oven at $110-115^{\circ} \mathrm{C}$. for 2-3 min., sprayed lightly with distilled water and reheated as before for some minutes, until yellow spots of meprobamate appear. Overheating should be avoided to prevent darkening of the chromatoplates. The spots, which disappear in about a day, have $R_{F} 0 \cdot 30$. Exact $R_{F}$ values are obtained only in the central zone of the ehromatograms; at the periphery of the plates $R_{F}$ values are higher, due to the border effect.

Unidentified impurities migrate with the solvent front (Fig. 1) and become violet under the sulphuric acid treatment.

A quantitative determination can be easily made by cutting out the spot and transferring it to a test tube. $1 \mathrm{ml}$. of distilled water is added, and then after careful shaking, $1 \mathrm{ml}$. of a 0.2 per cent hydroquinone in concentrated sulphuric $\mathrm{acid}^{3}$. The test tube is then heated in a boiling water bath for 20 min., till a yellow colour is obtained; this has an absorption maximum at $420 \mathrm{~m} \mu$ and can therefore be determined spectrophotometrically.

Further details will be published elsewhere.

Angelo Fiori

Mario Marigo

Istituto di Medicina Legale e delle

Assicurazioni,

Università di Padova. July 7.

1 Agranoff, B. W., Bradley, R. M., and Axelrod, J., Proc. Soc. Exp. Biol. Med., 96, 261 (1957)

'Ludwig, B. J., and Hoffman, A. J., Arch. Biochem. Biophys., 72 234 (1957).

${ }^{3}$ Riebeling, C., Arzneim.-Forsch., 7, 181 (1957).

${ }^{4}$ Demole, E., J. Chromatog., 1, 24 (1958).

- Reitsema, R. H., Anal. Chem., 26, 960 (1954).

${ }^{6}$ Kirchner, J. G., Miller, J. M., and Keller, G. J., Anal. Chem., 23, 420 (1951).

\section{Synthesis of 3,6-Dideoxy-D-ribo-hexose (3,6-Dideoxy-D-glucose) and its Identification with Paratose}

3,6-DIDEOXY-HEXOSES are a new class of natural sugars; five members of this group are known at present : abequose ${ }^{1}$, tyvelose ${ }^{12}$, paratose ${ }^{3}$ and colitose ${ }^{4}$ have been found in specific polysaccharides extracted from various species of Salmonella, and ascarylose is obtained by hydrolysis of three glycolipids (the ascarosides $A, B$ and $C$ ) extracted from the egg membrane and the cuticle of Parascaris equorum $^{5}$. We have shown that all these sugars are 3,6-dideoxy-hexoses ${ }^{6,7}$.

In a recent paper ${ }^{8}$, we reported the synthesis of 3,6-dideoxy-D-xylo-hexose (3,6-dideoxy-D-galactose) and 3,6-dideoxy-D-arabino-hexose (3,6-dideoxy$\mathrm{D}$-mannose) and showed that the first is identical with abequose and the second with tyvelose, while colitose is the optical antipode of abequose and ascaryllose is the optical antipode of tyvelose.

We now report the synthesis of 3,6-dideoxy-D-ribohexose (3,6-dideoxy-D-glucose) (III) and its identification with paratose.

3,6-Dideoxy-D-ribo-hexose (3,6-dideoxy-D-glucose) (III) was synthesized starting from 3-deoxy-D-ribohexose (3-deoxy-D-glucose) (I) kindly supplied by Drs. J. W. Pratt and N. K. Richtmyer ${ }^{9}$; the methylglucoside of this compound was tosylated, and after chromatography on magnesium silicate the methyl 3-deoxy-6-tosyl-D-ribo-hexoside (II) was obtained as a colourless syrup which was reduced by lithium aluminium hydride in a mixture of ether and benzene $(1: 1)$. After the usual treatment the methyl 3,6-dideoxy-D-ribo-hexoside was extracted with chloroform, the extract hydrolysed with $0.1 \mathrm{~N}$ hydrochloric acid in boiling water, and the free sugar then chromatographed on a column of Whatman cellulose powder. After elution of the sugar (II) with acetone/water $(95: 5)$ it was distilled at $0.05 \mathrm{~mm}$. and obtained as a colourless syrup, $[\alpha]_{D}+10 \pm 2^{\circ}$; $R_{F} 0 \cdot 71$ in butanol/pyridine/water $(6: 4: 3)$; calculated for $\mathrm{C}_{6} \mathrm{H}_{12} \mathrm{O}_{4}: \mathrm{C}, 48 \cdot 64 ; \mathrm{H}, 8 \cdot 16$ per cent ; found: $\mathrm{C}, 48 \cdot 68 ; \mathrm{H}, 8 \cdot 23$ per cent.

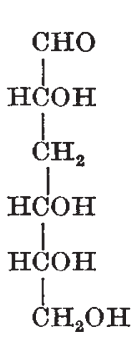

I

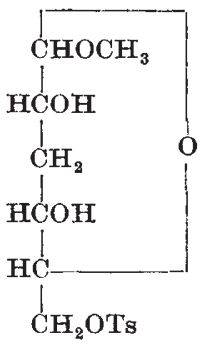

II

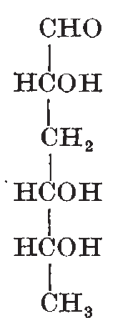

III

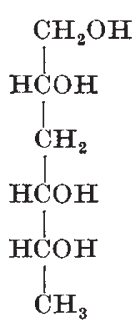

IV
The corresponding hexitol (IV) was prepared by reduction with sodium borohydride in water and obtained as crystals after distillation at $0.05 \mathrm{~mm}$. After recrystallization from acetone, 3,6-dideoxy-Dribo-hexitol (IV) was obtained as colourless needles, melting at $67-68^{\circ} ;[\alpha]_{D}-18 \pm 2^{\circ} ; R_{F} 0.53$ in butanol/pyridine/water $(6: 4: 3)$; calculated for $\mathrm{C}_{6} \mathrm{H}_{14} \mathrm{O}_{4}$ : C, 47.98 ; $\mathrm{H}, 9.40$ per cent; found: $\mathrm{C}, 47.93 ; \mathrm{H}, 9.68$ per cent.

Paratose, which has recently been isolated by Davies et al. ${ }^{3}$ from a polysaccharide of Salmonella paratyphi $A$, is a syrup, $[\alpha]_{D}+8 \pm 2^{\circ}$, and the hexitol (paratitol) obtained by reduction with sodium borohydride melts at $66-68^{\circ}$ and has $[\alpha]_{D}-16 \pm 2^{\circ}$. (Found: C, 47.61; H, 9.52 per cent.)

The mixed melting point of paratitol and 3,6dideoxy-D-ribo-hexitol (3,6-dideoxy-D-sorbitol) (IV) gave no depression. $R_{F}$ values and infra-red spectra of both paratose and the crystalline hexitol are identical with those of the respective synthetic compounds.
C. FOUQUEY
J. Polonsky
E. LEDERER

Institut de Biologie physico-chimique, Paris.

O. Westphat

O. LïDERITZ

Dr. A. Wander Forschungsinstitut, Freiburg-Zähringen.

${ }^{1}$ Westphal, O., Lüderity, O., Fromme, I., and Joseph, N., Angew. Chemie, 65, 555 (1953).

${ }^{2}$ Pon, G., and Staub, A. M., Bull. Soc. Chim. Biol., 34, 1132 (1952). Davies, D. A. L., Fromme, I., Lüderitz, O., Staub, A. M., and Westphal, O., Nature, 181, 822 (1958).

Lüderitz, O., Staub, A. M., Stirm, St., and Westphal, O., Biochem. $Z$., 330, i93 (1958).

${ }^{5}$ Fouquey, C., Polonsky, J., and Lederer, E., Bull. Soc. Chim. Biol., 39, 101 (1957).

- Fromme, I., Himmelspach, K., Lüderitz, O., and Westphal, O., Angew. Chemie, 69, 643 (1957).

'Fouquey, C., Polonsky, J., and Lederer, E., Bull. Soc. Chim. Biol., 40,315 (1958).

${ }^{8}$ Fouquey, C., Lederer, E., Lüderitz, O., Polonsky, J., Staub, A. M. Stirm, S., Tinelli, R., and Westphal, O., C.R. Acad. Sci., Paris, 248, 2417 (1958)

Pratt, J. W., and Richtmyer, N. K., J. Amer. Chem. Soc., 79, 2597 (1957). 